DOI https://doi.org/10.36059/978-966-397-160-5/18-33

\title{
"FAKE" NEWS VIA THE COMIC: DISTORTION OF INFORMATION
}

\section{Yuliia Hlavatska}

\section{INTRODUCTION}

Fake News has become an art form

A. E. Samaan

The comic occupies an important place among the logico-philosophical and aesthetic categories. Philosophers, literary critics and linguists have focused on it for a long time. The nature of humour was in the focus of ancient scholars' interest (Plato, Aristotle, Cicero, Quintilian) whose works became the basis for the formation of further comic theories explaining this phenomenon in various scientific branches such as psychology, sociology, philosophy, biology, literature and linguistics.

The philosophy of the last two centuries pays great attention to the nature of the comic distinguishing its two forms: the first one is connected with the behaviour of subjects, situations and a human being's actions, which are perceived as contradicting to the generally accepted; the second form is created by the language itself and expressed by linguistically unusual logical or semantic constructions.

The sphere of untruth/lying is mostly oral. In general the written version of untruth is the tendency of presenting facts in the media. «Fake» news is a kind of media text that is defined as a dynamic, complex unit of high level by means of which speech communication in the sphere of mass communication is conducted and it is a creolized, polycodic, integrative text (with verbal, visual, audiovisual constituants) ${ }^{1}$.

The topicality of our research is determined by its relevance to the priority anthropocentric tendencies of modern linguistics, the absence of reasonable analysis of the means of implementation of the comic in general as well as humour, irony, satire and sarcasm in particular in "fake" news texts.

\footnotetext{
${ }^{1}$ Kuz'mina N. A. (2011) Sovremennyy mediatekst [Modern mediatext]. Omsk: Tat'yana. (in Russian)
} 
A comprehensive and profoud study of «fake» news as a genre of modern English-language media discourse was presented in the dissertation thesis made by $\mathrm{Yu}$. Omelchuk ${ }^{2}$. The scientific research presents the description of the linguistic, cognitive, communicative and pragmatic parameters of "fake" news texts.

In particular the category of the comic and the means of its verbalization are represented in many scientific works (A. Boldyrieva, Y. Hlavatska, A. Kutoian, T. Liubymova, V. Propp, etc.). A thorough study of the comic is presented in the monograph of V. Samokhina ${ }^{3}$; a profound analysis of the actualization of the comic in non-fiction critical texts is given in the collective monograph of Kharkiv Scientific School under the guidance of professor Pikhtovnikova ${ }^{4}$.

The objective of this paper is the studying of the complex and ambiguous phenomenon of the comic which is transmitted directly through the language in "fake" news texts. The achievement of the objective involves characterizing the main types of the comic and analyzing the means of expressing the comic in the texts of "fake" news via its functions and classifications.

\section{Irony and sarcasm in "fake" news texts: drawing attention to important social issues}

Synthesizing all the information as for the comic we can conclude that the comic in any type of text is aimed at ensuring the dominant functions and purposes of a particular genre and, accordingly, through its means it promotes the implementation of its laws. We have already focused our attention on "fake" news texts themselves, their functions" and key classifications ${ }^{6}$.

2 Omelchuk Yu. O. (2018) Psevdonovyny yak zhanr suchasnoho anhlomovnoho mediadyskursu: linhvokohnityvnyi, komunikatyvno-prahmatychnyi parametr [Pseudo news as a genre of modern English media discourse: linguistic, cognitive, communicative and pragmatic parameters] (PhD Thesis), Zaporizhzhia: Zaporizhzhia National University.

${ }^{3}$ Samohina V. O. (2012) Zhart u suchasnomu komunikatyvnomu prostori Velykoi Brytanii ta SShA [A Joke in today's communicative space of the UK and the US]. Kharkiv: KhNU imeni V. N. Karazina. (in Ukraine)

${ }^{4}$ Pichtovnikova L. S., Masterova O. Ya., Kabus' E. P. (2016) Nemetskoyazychnyye publitsisticheskiye teksty sotsial'no-kriticheskogo napravleniya: pragmastilisticheskiy $i$ kognitivnyy aspekty [German-speaking non-fiction critical texts: pragmastylistic and cognitive aspects]. Kharkiv: KhNU imeni V. N. Karazina. (in Russian)

5 Hlavatska Yu. L. (2018) "Fake" news functions: historical background of their development. Scientific Bulletin. Linguistics, no. 34, pp. 150-152.

${ }^{6}$ Hlavatska Yu. L. (2019) Klasyfikatsiia feikovykh novyn u suchasnomu mediaprostori: synerhetychnyi aspect [Classification of "fake" news in modern media space: synergrtic aspect]. Germanic studies and intercultural communication, no. 1, pp. 275-280. 
Extrapolating O. Kozyntsev's scientific heritage, humour and satire are considered subtypes of the comic ${ }^{7}$, as full forms of the comic ${ }^{8}$, and irony and sarcasm, following N. Arutiunova ${ }^{9}$, defined as types of comic sense (meanings). The difference between the above subtypes of the comic (humour and satire) and comic meanings (irony and sarcasm) occurs in terms of mockery (or shades of laughter) ${ }^{10}$.

Thus, the subtypes of the comic described above provide a fertile ground for identifying and describing the comic verbalization in non-fiction critical texts - "fake" news. In the context of our work, based on the analysis of factual material, we focused on the texts of "fake" news which, according to well-known classifications ${ }^{11}$, are presented in the form of a text, belong to the field of politics, sports and social problems by topic, intended for young people and for people of any age and given from the first source - that is, those websites that directly post such news in the media (classification by M. Kitsa) ${ }^{12}$. According to the purpose of creating "fake" news we have selected to find out the means of expressing the comic there are texts drawing attention to important social issues, misleading the recepient and discrediting the opponent. In general according to the classification of D. Lavnikevich) ${ }^{13}$ they are created for entertainment. As for the criterion for

${ }^{7}$ Kozintsev A. G. (2007) Yumor: do i posle ironii [Humour: before and after irony]. Logicheskiy analiz yazyka. Yazykovyye mekhanizmy komizma [Logical language analysis. Language mechanisms of the comic]. Moscow: Indrik, pp. 238-253.

8 Shon O. B. (2003) Movnostylistychni zasoby realizatsii humoru, ironii $i$ satyry $v$ amerykanskomu korotkomu opovidanni [Linguistic means of humour, irony and satire verbalization in American short story] Extended abstract of Candidate's thesis). Lviv. (in Ukrainian)

${ }^{9}$ Arutyunova N. D. (2007) Esteticheskiy i antiesteticheskiy aspekty komizma [Aesthetic and antiaesthetic aspects of the comic]. Logicheskiy analiz yazyka. Yazykovyye mekhanizmy komizma [Logical language analysis. Language mechanisms of the comic]. Moscow: Indrik, pp. 5-17.

${ }^{10}$ Trach A. S. (2007) Ekonomiya i izbytochnost' segmentnykh sredstv v komicheskom tekste (na materiale proizvedeniy M.M. Zhvanetskogo) [Savings and redundancy of segment means in a comic text (the case study of M.M. Zhvanetsky's works)]. Logicheskiy analiz yazyka. Yazykovyye mekhanizmy komizma [Logical language analysis. Language mechanisms of the comic]. Moscow: Indrik, pp. 175-185.

${ }^{11}$ Hlavatska Yu. L. (2019) Klasyfikatsiia feikovykh novyn u suchasnomu mediaprostori: synerhetychnyi aspect [Classification of "fake" news in modern media space: synergrtic aspect]. Germanic studies and intercultural communication, no. 1, pp. 275-280.

${ }^{12}$ Kitsa M. O. (2016) Feikova informatsiia v ukrainskykh sotsialnykh media: poniattia, $v y d y$, vplyv na audytoriiu [Fake information in Ukrainian social media" concepts, types, impact on audience]. Scientific Notes. Social communications, no. 1 (52), pp. 281-286.

13 Lavnikevich D. Feyki kak novaya mediareal'nost' [Fakes as new mediareality]. Retrieved from: http://mediakritika.by/article/3573/feyki-kak-novaya-media-realnost (accessed 23 December 2018). 
submitting "false" content (classification by C. Wardle) ${ }^{14}$, the focus of our scientific research is the satire / parody content of "fake" news.

Irony is a subtle mockery, hidden with the help of the allegory, denying under the guise of consent; a mocking assessment of the described subject or phenomenon. The comical effect arises as a result of recognizing the object of a parody, the main element here is a successful imitation ${ }^{15}$.

An example of the realization of irony is the "fake" news "Cockroaches feeling very optimistic about future of planet", published on the website "The Onion"16. The entire text of the "fake" news is based on the principle of the social poll of cockroaches on an environmental issue, now becoming relevant in modern society: The poll, which surveyed 500 million of the nocturnal scavenging insects, found that more than 95 percent believe the environment is headed in the right direction, and that in the coming years the conditions in their sewer, rotted-wood, and residential habitats stand to improve dramatically. Such a choice of form of news broadcasting illustrates the ironic allegory at macro context as the title indicates - «Cockroaches feel too optimistic about the future of the planet». Lexical allogism as a mean of expressing irony is used in the title, since the title contains concepts that are opposed to each other - cockroaches and very optimistic. Moreover, such "optimism" is supported by a number of lexical units with an emotional colouring, which we observe throughout the text: highly optimistic, be encouraged, without worrying, dramatic shift, my complete faith, enthusiasm.

The image of cockroaches participating in the social poll starts to be created at the text level by introducing their ironic "names" and places of residence like a 6-month-old brown-banded cockroach from a Queens, NY, bathtub drain; a 7-week-old German cockroach from a Minneapolis-area pile of decaying leaves. The verbalization of their thoughts and evaluations completes the creation of their ironic images: It just puts my mind at ease to know my hundreds of kids are going to inherit a planet where they can thrive and where they can one day deposit their own egg cases without worrying; Even though progress has not always been smooth, I'm more and more

14 "Fake" news. Retrieved from: https://www.bbc.com/ukrainian/other-news-russian41846967 (accessed 23 December 2018).

${ }^{15}$ Izdyk Yu. (2006) Ironiia nad ironichnistiu [Irony over irony]. Lviv: Litopys, Kuiv: Smoloskyp, pp. 143-144.

16 Cockroaches feeling very optimistic about future of planet. Retrieved from: http://www.golfonline.ru/augusta-national-golf-club (accessed 19 October 2019). 
confident that the planet is on the right track and that roaches are going to be okay ${ }^{17}$.

The ironic subtext of the "fake" news is based on the incompatibility of the attributes - the presentation of the percentage result of the so-called "poll" and references to reasonable decisions of world leaders. The following examples illustrate this view: Across species, cockroaches offered robust support for prevailing trends in environmental policy, with 86 percent expressing enthusiasm for technologies such as fracking and open-pit mining, 81 percent praising the growing demand for disposable consumer goods, and 84 percent saying they were happy with the amount of industrial runoff in ground soil. Another 4 percent reportedly skittered away beneath a baseboard crevice before answering any questions; it's because of the prudent decisions that are being made by world leaders as we speak.

In the represented sentences lexico-syntactic allogism diverges across all lines of material submission, namely: providing digital proof of the «participants» of the poll; the use of nominative units with emotional colouring (robust support, expressing enthusiasm, praising); use of terminological lexemes (fracking, open-pit mining, industrial runoff in ground soil). All above allogisms show the reality, reveal the contradictions, while causing the ironic effect of the contradiction of the form and the content.

The above example signals the hyperbolization of real facts by creating an artificial grotesque situation. The formal plausibility that we can observe in the media, especially during the election campaign, or as a certain percentage, is disturbed in the text of the "fake" news being analyzed by the fact that the statement of facts is grotesque.

Therefore, the essence of irony is that it manifests a conflict of meaningless content with an outwardly decent, respectable form. Irony as "proof of the opposite" demonstrates the utter absurdity and hyperbolization of such a phenomenon as a global environmental problem. The discrepancy between the style of expression and its context gives rise to the realization of a modality of negative character.

Sarcasm is acrimonious, revelatory, sneering mockery full of contempt. Sarcasm is considered to be a kind of the comic, sharp emotional evaluation of phenomena without overtones, that differs it from the close meaning of irony ${ }^{18}$. The illustration of sarcasm realization is the text of the "fake" news

17 Cockroaches feeling very optimistic about future of planet. Retrieved from: http://www.golfonline.ru/augusta-national-golf-club (accessed 19 October 2019).

${ }^{18}$ Izdyk Yu. (2006) Ironiia nad ironichnistiu [Irony over irony]. Lviv: Litopys, Kuiv: Smoloskyp, pp. 143-144. 
"Trump starts border wall himself" being posted on the site "Unconfirmed Sources" $"$. The real media source proves that the President of the United States, Donald Trump, ordered to build the wall along the US border with Mexico. The President of Mexico, Enrique Peña Nito, at once condemned this step and stated that his country was not payable for business expenses. At the same time several leaders of Latin America expressed their indignation at the decision to build the wall that is being reported by «Radio Liberty» in Ukraine ${ }^{20}$.

The text of the "fake" news reports that Donald Trump himself wants to build his wall: Mr. Trump decided the only way to get this job done right was to do it himself. The reader understands that this is a wall with Mexico. Place-names Mexico and Guatemala indicate this.

The urgency of a real political phenomenon (building a wall between Mexico and the USA), revealing its sarcastic essence, and demonstrating absurdity contribute to the creation of a sarcastic image-symbol of Donald Trump, which is visually presented in a photo fake ${ }^{21}$. Verbally, this image is supported by a number of lexical units of the opposite meaning - large and small; the use of the phrase hands-on manager, which has the meaning the head of vocational training, but in this context it is ironic (the master in the construction business of large and small projects): Known as a hands-on manager of construction projects large and small ... .

Sarcasm is ensured by such a stylistic device as exaggeration, which, in its turn, is enhanced by fictional (fake, false) drama. This is indicated by the thesis from the news that only a few workers want to work under such unpleasant and annoying conditions: there are few laborers willing to work in such harsh conditions.

In the text of the «fake» news an image of a brickstacker arises - a certain Tim Handerson. We consider this image to be a parody of the former Secretary of State for US Internal Security, Tom Bossert (he resigned in 2017), whose competence was illegal immigration in general, and illegal immigration of Hispanics to the USA.

At the verbal level, Tim Handerson is able to help Donald Trump, but his "minor" help is updated through the pronoun some and the phrase several minutes, which is part of the sentence: Handerson and Mr. Trump worked together for several minutes.

${ }^{19}$ Trump starts border wall himself. Retrieved from: http://unconfirmedsources.com/wp/trumpstarts-building-border-wall-himself/ (accessed 15 October 2019).

20 Radio Svoboda Ukrainy [Radio Liberty of Ukraine]. Retrieved from: https://www.radiosvoboda.org/a/28261560.html (accessed 15 October 2019).

${ }^{21}$ Trump starts border wall himself. Retrieved from: http://unconfirmedsources.com/wp/trumpstarts-building-border-wall-himself/ (accessed 15 October 2019). 
The absurdity of the situation presented in the text of the "fake" news reinforced by the symbolization of the negative essence of building such a wall as a social object, which must be destroyed without starting the building. The sarcastic expression of the absurdity occurs with the help of allogisms, that is, a comparison of what cannot be matched or compared, and with the help of hyperbolization. The following examples from the text of the news illustrate this opinion: Mr. Trump then took a quick break to sign bricks for his fellow wall builders and throw rocks at curious Mexican children who had come by to watch the spectacle $e^{22}$.

As you can see, the whole idea is the unfortunate intention of the US president on a problem that is in the focus of attention, it's just a performance, a spectacle associated with the signing of bricks and throwing stones in the direction of curious Mexican children.

Noteworthy is the lexical unit yuge, which is represented by capitalization in the "fake" news: "Well, Tim," said Mr. Trump. "I brought my favorite trowel. Let's get to work on this YUGE beautiful wall!". Firstly, yuge is a phonetic rendition of huge as an imitation of the New York accent; secondly, in the context the word symbolizes the so-called «grandeur» of the Mexican wall; thirdly, this lexical unit acquires an ironic connotation in the aspect of phonetic design as well as of capitalization.

Thus, the essence of sarcasm realization is manifested in the grotesque, parody and absurdity of the situation described, the unfolding of the conflict: the "vivid" description of events in the text of the "fake" news is incompatible with real world events. The explicitness (unmasked description) of contempt and a scathing mockery testify to the admissibility of falsehood and fantasy, far from true events. The above thesis illustrates the last sentence of the «fake» news: Mr. Trump then toured a border command post and helped escort a group of undocumented immigrants from Guatemala back over the border into Mexico ${ }^{23}$.

\section{Humour and satire in "fake" news texts: misleading the recepient and discrediting the opponent}

Unlike the other forms of the comic representation (irony, satire, sarcasm) humour is characterized by a benevolent attitude to life and manifestations of its imperfection; this is the laughter, which is combined with sympathy for the one to whom or what it is aimed at, that is, a

\footnotetext{
${ }^{22}$ Trump starts border wall himself. Retrieved from: http://unconfirmedsources.com/wp/trumpstarts-building-border-wall-himself/ (accessed 15 October 2019).

${ }^{23}$ Trump starts border wall himself. Retrieved from: http://unconfirmedsources.com/wp/trumpstarts-building-border-wall-himself/ (accessed 15 October 2019).
} 
psychologically positive phenomenon ${ }^{24}$. Humour can be realized at the level of words, phrases, sentences and text fragments ${ }^{25}$.

So, the website «Sports Pickle» refers to humorous website covering the world of sports. The "fake" news "Augusta National installs artificial turf to save on mowing costs" ${ }^{\prime 26}$ states that the management of the Augusta National Golf Club, which is one of the most famous golf clubs in the world, is confident that artificial court coverage will save $\$ 3.2$ million in expenses each year-Augusta officials believe the synthetic surface will save more than \$3.2 million in course upkeep costs each year. Although due to true sourses of information unlike most private clubs which operate as nonprofits, Augusta National is a for-profit corporation, and it does not disclose its income ${ }^{27}$.

The situation described in the text of the "fake" news, which is under analysis, is incompatible and contradictory (incongruent - in terms of V. Samokhina ${ }^{28}$ ), because the background knowledge of the recipient and the presence of reliable sources concerning the National Golf Club's state about the natural possibilities of the plot of land, natural reservoirs, natural grass covering, etc. ${ }^{29}$. Therefore, the theses in the text of the "fake" news like bright green fake grass and the white and pink plastic azaleas, artificial turf intend to make laugh, and the addresser deliberately hyperbolizes and misleads the addressee. According to V. Samokhina the addresser

${ }^{24}$ Propp V. Ya. (1976) Problemy komizma i smekha [The problems of the comic and laughter]. Moscow: Iskusstvo. (in Russian)

25 Tytarenko O. Iu. (1993) Movni zasoby vyrazhennia humoru (na materiali tvoriv anhliiskoi ta amerykanskoi literatury XIX-XX stolit [Language means of humour expressing (the case study of the English and American literature of the XIX-XXth centuries)] Extended abstract of Candidate's thesis). Kyiv. (in Ukrainian)

${ }^{26}$ Augusta National installs artificial turf to save on mowing costs. Retrieved from: http://sportspickle.com/news/augusta-national-installs-artificial-turf-to-save-on-mowingcosts.html (accessed 19 October 2019).

${ }^{27}$ Augusta National Golf Club. Retrieved from: http://www.golfonline.ru/augusta-nationalgolf-club (accessed 19 October 2019).

${ }^{28}$ Samohina V. O. (2012) Zhart u suchasnomu komunikatyvnomu prostori Velykoi Brytanii ta SShA [A Joke in today's communicative space of the UK and the US]. Kharkiv: KhNU imeni V. N. Karazina. (in Ukraine)

${ }^{29}$ Augusta National Golf Club. Retrieved from: http://www.golfonline.ru/augusta-nationalgolf-club (accessed 19 October 2019). 
deliberately misleads the addressee creating the effect of deceived expectation, which is a combination of stylistic devices ${ }^{30}$.

At the word level humour is realized through a series of synonyms (artificial, fake, plastic, synthetic) which contrast with the naturalness of the coverage of the famous club's courts (The club is famed for its azaleas and $\left.\operatorname{dog}_{\text {woods }}{ }^{31}\right)$.

In the phrase pipe soothing bird noises, which is part of the sentence So we will now pipe soothing bird noises in across the course, as well as some subtle piano music, the comical effect is based on the word play with the direct meaning of the verb to soothe - reassure and the noun sooth-true, truth, which in this context can be interpreted in two ways -artificial calming bird sounds as well as real ones. The polysemy in this context contributes to a different reading as well as to the incorrect perception of the referent as such, which differs from the expected one and it gives rise to a humorous effect. In addition, the verb pipe (playing the pipe) again emphasizes the semantic load of the key noun of this "fake" news - artificial which is illogical in terms of the recipient's background knowledge.

Incongruence is a game of contradictions, oppositions, incompatibilities which provokes the creation of the conflict in the context of the situation "Do you have any idea how many chemicals are spread over a golf course?» said Payne. "Anyone who thinks golf courses are unspoiled nature are living in a dream world. Our new course does not use a single chemical - well, outside of the thousands of gallons of petroleum used to make the grass". The illogical combination of the nominative units unspoiled nature and chemical contributes to the creation of the conflict within the situation.

The last sentence of the "fake" news, that is being analyzed, illustrates an unexpected comparison of Jim Nanz, a famous sports commentator, American athlete, with a robot: «Jim Nantz will be replaced by a human-like robot,» said the chairman. "I do not think viewers will notice much of a difference» ${ }^{32}$.

${ }^{30}$ Samohina V. O. (2012) Zhart u suchasnomu komunikatyvnomu prostori Velykoi Brytanii ta SShA [A Joke in today's communicative space of the UK and the US]. Kharkiv: KhNU imeni V. N. Karazina. (in Ukraine)

${ }^{31}$ Augusta National Golf Club. Retrieved from: http://www.golfonline.ru/augusta-nationalgolf-club (accessed 19 October 2019).

32 Augusta National installs artificial turf to save on mowing costs. Retrieved from: http://sportspickle.com/news/augusta-national-installs-artificial-turf-to-save-on-mowingcosts.html (accessed 19 October 2019). 
Thus, the essence of the implementation of humour is removing of formal credibility by replacing the real facts with an artificial, fictional, "distorted" situation, and the humour of this "fake" news evokes only a smile, and is based on the methods of wit and semantic play.

Satire is a kind of the comic, the object of ridicule is society, social vices of wide public significance, violations of the norms of morality that the author aims to criticize, ridicule, disapprove, but at the same time, he gives the ridicule a chance to be corrected, showing his behaviour from the side ${ }^{33}$.

The implementation of satire is monitored by three news content - two news texts are published on well-known Internet wallpapers ("Huffpost", "The Washington Post"), and the other is "the property" of "NewsBiscuit" site. Anthony Scaramucci is an American financier, entrepreneur, and political consultant who briefly served as the White House Director of Communications from July 21 to July 31, 2017 in the spotlight.

In the text of the news "The Trump White House: No Fandango! Fake news!"34, taken from the "Huffpost", we trace the allusion to D. Trump's government as a circus, and A. Scaramucci as a comedy character, a clown in it (Scaramouche - the mask of Italian comedy). According to the content of this article D. Trump's real reaction is that he does not compare his former assistant of communications to a swindler, a clown, a thief: It follows, therefore, that any reference to «doing the fandango» ("Scaramouche, Scaramouche, will you do the Fandango?") is clearly FAKE NEWS from the LYING PRESS! Scaramucci is not Scaramouche. In this statement we observe a quote on the lyrics of the Queen band "Scaramouche, Scaramouche, will you do the Fandango?". In addition, fandango is a lyrical, sublime, and passionate, with lively subtle moving dance; it's a dance of lovers. In some cases, fandango also takes the form of a skill contest, the question «Scaramouche, Scaramouche, will you do the Fandango» sounds like a challenge and an obvious threat to a young competitor.

${ }^{33}$ Khudaverdova N. P. (2012) Komicheskoye i smekh v istorii mirovoy esteticheskoy mysli [Comic and laughter in the history of world aesthetic thought]. Retrieved from: http://publishing-vak.ru/file/archivephilosophy-2012-2/6khudavedrova.pdf (accessed 23 December 2018).

34 The Trump White House: No Fandango! Fake news!. Retrieved from: https://www.huffingtonpost.co.uk/robin-lustig/the-trump-white-house_b_17610374.html (accessed 22 December 2018). 
We think in the context of this "fake" news polysemy as a stylistic feature can be observed, the essence of which is in the two-sidedness of polar points of view which further enhances the satirical nature of the image and contributes to the creation of the comic effect.

In the text "What is the Scaramucci Post? "We have absolutely no idea, ${ }^{35}$, taken from "The Washington Post", we trace the satirical attitude towards A. Scaramucci. The author of the article, Derek Hawkins, laughes explicitly calling A. Scaramucci a Little Muck: What is the Scaramucci Post, exactly? No one really knows for certain - not even The Mooch himself, and his tenure in the government of D. Trump - 10-seconds: Also I just asked him to explain the Scaramucci Post in 10 secs and he was like actually we have no idea what it is is yet, thus forming a caricature as a quick reflection of social events.

And in the text of the "fake" news "Scientists discover new particle, the Scaramuccion»" taken from the "NewsBiscuit" website, the author implicitly, again, by means of satire, calls Scaramucci - The Scaramucciona new physical particle that quickly disappears because of a very short period of time: Scientists working at the CERN particle accelerator have discovered an entirely new particle, the Scaramuccion, which they admit they almost missed because it only existed for such an infinitesimally short period of time. On the other hand, the author openly mocks at Anthony Scaramucci and his fortune: Tony from the neighborhood, just a poor boy from a poor family. So, we continue to oversee the creation of a caricature image - the replacement of the world-famous person by the name The Scaramuccion.

It should be noted that the nominative unit Scaramuccion refers to lexical allogism, a linguistic and stylistic means of satire, which combines parts of words: the beginning of the word is the name of A. Scaramucci, and the end of the word is a traditional Latin marking like proton, positron electron. That is, in our opinion, one can consider a such neologism as a result of the word play as a means of creating a satirical effect.

35 What is the Scaramucci Post? 'We have absolutely no idea! Retrieved from: pic.twitter.com/1CyGJXG04u (accessed 20 December 2018).

36 Scientists discover new particle, the Scaramuccion. Retrieved from: http://www.newsbiscuit.com/2017/08/02/scientists-discover-new-particle-the-scaramuccion/ (accessed 19 December 2018). 
The dual meaning of the lexical unit is the means of satire expression. For example, some scientists believe that Scaramuccion should be attributed to quarks (elementary particles and fundamental constituent of matter, combining to create composite particles, hadrons, the most stable of which are protons and neutrons, the components of atomic nuclei): Some thought it might be a type of quark, though clearly not from the "charm" side of the family. The use of the nominative unit "charm" given in quotation marks points out the disadvantages of a «newly formed particle» since there is a socalled «charmed quark» in nature. And the phrase not from the "charm" side of the family confirms the existence of satirical effect as synonymous for the phrase just a poor boy from a poor family.

The satirical nature of the situation and the caricature of the image (its hyperbolization) is intensified by the fact that at the end of the "fake" news we are confronted with the thesis that this "pretty particle" serves as a catalyst, an accelerator, in our case, of the events that don't make us wait for the appearance of a new person in US President's environment: This is a pretty nice particle accelerator ya got here - be an awful shame if anything happened to it... ${ }^{37}$.

The confirmation of this is given from official media sources that the fourth (following A. Scaramucci) White House communications director for President D. Trump was Hope Hicks, who resigned in March, 2018. In summer 2018, a former producer and executive at Fox News, Bill Shain, was appointed the White House Deputy Chief of Staff for Communications director for the fifth time in the administration of US President.

Therefore, the essence of satire realization is manifested in two ways the explicit caricature image, on the one hand, and implicit comic implication, that is the reconstruction of a satirical symbolic image (the image of Donald Trump), the sharp critical mockery of his negative features.

\section{CONCLUSIONS}

The study of the text of the «fake» news is carried out precisely within the anthropocentric scientific paradigm, since a human being and his activity, on the one hand, and the comic as a reflection of the contradictions of social life, on the other hand, are key ones in the text of such news. The

37 Scientists discover new particle, the Scaramuccion. Retrieved from: http://www.newsbiscuit.com/2017/08/02/scientists-discover-new-particle-the-scaramuccion/ (accessed 19 December 2018). 
results of the theoretical material (methods of synthesis, induction, deduction) testify the difference between humour and satire, irony and sarcasm lies in the quality of the mockery.

The dominant means of irony verbalization include lexico-syntactic allogisms and hyperbolization. The ironic situation of the "fake" news is based on the incompatibility of the presentation of its form and content, the absurdity of the events described in the text of the "fake" news. Sarcasm is accompanied by hyperbolization which is forced by fictional drama, on the one hand, and symbolization of the negative nature of the phenomenon, on the other hand. The parody and absurdity of the description of the situation provoke the formation of contempt, a mocking mockery that testify to the permissibility of falsehood and fabrication, far from true events. The dominant function of irony and sarcasm is drawing attention to important social issues.

The incompatibility (incongruence as a word play), which is actualized at the level of words, phrases, sentences and communicative situation in general, is the main means of humour implementation in the text of "fake" news. The essence of the actualization of humour lies in the fact that in the text of the «fake» news we observe the removal of formal plausibility by replacing the real facts with a «distorted» situation, and humour belongs to the gallery of non-malicious laughter. By means of humour the author of "fake" news misleads the reader as for factual events. The verbatization of satire as a subtype of the comic is characterized by the reconstruction of a caricature image as the reflection of discrediting the political opponent.

Our further plans deal with the studying of cognitive principles of decoding comic information or the so-called «pseudo-sense» which is embedded in the text of «fake» news.

\section{SUMMARY}

The article focuses on the dominant ways of the comic actualization of irony and sarcasm as the types of comic sense, humour and satire as full forms of the comic in "fake" news. The comic is based on the discrepancy or contradiction between the form and the content, the aim and the ways of its achievement, visibility and essence. The difference between subtypes of the comic lies in the shade of laughter and orientation to a particular phenomenon / object. In media space «fake» news «distorts» real events, things, feelings and it appears to be deceptive, false, masquerade. Such a 
«twist» is characterized by humorous or satirical colouring. "Fake" news demonstrates intentional misrepresentation as a means of discriminating a certain person or group of individuals; misinformation, misleading of the reader; infotainment; drawing attention to key social issues etc. Irony illustrates the complete absurdity and hyperbolization of a social phenomenon; grotesque and parody arise the conflict resulted in unmasked presentation of contempt. Humour is based on the author's witty tricks and semantic word play not excluding the form of presentation; satire discrediting the person favours the creation of a caricature image.

\section{REFERENCES}

1. Arutyunova N. D. (2007) Esteticheskiy i antiesteticheskiy aspekty komizma [Aesthetic and anti-aesthetic aspects of the comic]. Logicheskiy analiz yazyka. Yazykovyye mekhanizmy komizma [Logical language analysis. Language mechanisms of the comic]. Moscow: Indrik, pp. 5-17.

2. Augusta National Golf Club. Retrieved from: http://www.golfonline.ru/augusta-national-golf-club (accessed 19 October 2019).

3. Augusta National installs artificial turf to save on mowing costs. Retrieved from: http://sportspickle.com/news/augusta-national-installsartificial-turf-to-save-on-mowing-costs.html (accessed 19 October 2019).

4. Cockroaches feeling very optimistic about future of planet. Retrieved from: http://www.golfonline.ru/augusta-national-golf-club (accessed 19 October 2019).

5. "Fake" news. Retrieved from: https://www.bbc.com/ukrainian/othernews-russian-41846967 (accessed 23 December 2018).

6. Hlavatska Yu. L. (2018) "Fake" news functions: historical background of their development. Scientific Bulletin. Linguistics, no. 34, pp. 150-152.

7. Hlavatska Yu. L. (2019) Klasyfikatsiia feikovykh novyn u suchasnomu mediaprostori: synerhetychnyi aspect [Classification of "fake" news in modern media space: synergrtic aspect]. Germanic studies and intercultural communication, no. 1, pp. 275-280.

8. Izdyk Yu. (2006) Ironiia nad ironichnistiu [Irony over irony]. Lviv: Litopys, Kuiv: Smoloskyp, pp. 143-144.

9. Khudaverdova N. P. (2012) Komicheskoye i smekh v istorii mirovoy esteticheskoy mysli [Comic and laughter in the history of world aesthetic 
thought]. Retrieved from: http://publishing-vak.ru/file/archivephilosophy2012-2/6khudavedrova. pdf (accessed 23 December 2018).

10. Kitsa M. O. (2016) Feikova informatsiia v ukrainskykh sotsialnykh media: poniattia, vydy, vplyv na audytoriiu [Fake information in Ukrainian social media" concepts, types, impact on audience]. Scientific Notes. Social communications, no. 1 (52), pp. 281-286.

11. Kozintsev A. G. (2007) Yumor: do i posle ironii [Humour: before and after irony]. Logicheskiy analiz yazyka. Yazykovyye mekhanizmy komizma [Logical language analysis. Language mechanisms of the comic]. Moscow: Indrik, pp. 238-253.

12. Kuz'mina N. A. (2011) Sovremennyy mediatekst [Modern mediatext]. Omsk:Tat'yana (in Russian)

13. Lavnikevich D. Feyki kak novaya mediareal'nost' [Fakes as new mediareality]. Retrieved from: http://mediakritika.by/article/3573/feyki-kaknovaya-media-realnost (accessed 23 December 2018).

14. Omelchuk Yu. O. (2018) Psevdonovyny yak zhanr suchasnogo anglomovnogo mediadyskursu: lingvokognityvnyi, komunikatyvnopragmatychnyi parametry [Pseudo news as a genre of modern English media discourse: linguistic, cognitive, communicative and pragmatic parameters] (PhD Thesis), Zaporizhzhia: Zaporizhzhia National University.

15. Pichtovnikova L. S., Masterova O. Ya., Kabus' E. P. (2016) Nemetskoyazychnyye publitsisticheskiye teksty sotsial'no-kriticheskogo napravleniya: pragmastilisticheskiy i kognitivnyy aspekty [German-speaking non-fiction critical texts: pragmastylistic and cognitive aspects]. Kharkiv: KhNU imeni V. N. Karazina. (in Russian)

16. Propp V. Ya. (1976) Problemy komizma i smekha [The problems of the comic and laughter]. Moscow: Iskusstvo. (in Russian)

17. Radio Svoboda Ukrainy [Radio Liberty of Ukraine]. Retrieved from: https://www.radiosvoboda.org/a/28261560.html (accessed 15 October 2019).

18. Samohina V. O. (2012) Zhart u suchasnomu komunikatyvnomu prostori Velykoi Brytanii ta SSHA [A Joke in today's communicative space of the UK and the US]. Kharkiv: KhNU imeni V. N. Karazina. (in Ukraine)

19. Scientists discover new particle, the Scaramuccion. Retrieved from: http://www.newsbiscuit.com/2017/08/02/scientists-discover-new-particlethe-scaramuccion/ (accessed 19 December 2018).

20. Shon O. B. (2003) Movnostylistychni zasoby realizatsii humoru, ironii $i$ satyry $v$ amerykanskomu korotkomu opovidanni [Linguistic means of 
humour, irony and satire verbalization in American short story] Extended abstract of Candidate's thesis). Lviv. (in Ukrainian)

21. The Trump White House: No Fandango! Fake news!. Retrieved from: https://www.huffingtonpost.co.uk/robin-lustig/the-trump-whitehouse_b_17610374.html (accessed 22 December 2018).

22. Trach A. S. (2007) Ekonomiya i izbytochnost' segmentnykh sredstv $v$ komicheskom tekste (na materiale proizvedeniy M.M. Zhvanetskogo) [Savings and redundancy of segment means in a comic text (the case study of M.M. Zhvanetsky's works)]. Logicheskiy analiz yazyka. Yazykovyye mekhanizmy komizma [Logical language analysis. Language mechanisms of the comic]. Moscow: Indrik, pp. 175-185.

23. Trump starts border wall himself. Retrieved from: http://unconfirmedsources.com/wp/trump-starts-building-border-wallhimself/ (accessed 15 October 2019).

24. Tytarenko O. Iu. (1993) Movni zasoby vyrazhennia humoru (na materiali tvoriv anhliiskoi ta amerykanskoi literatury XIX-XX stolit [Language means of humour expressing (the case study of the English and American literature of the XIX-XXth centuries)] Extended abstract of Candidate's thesis). Kyiv. (in Ukrainian)

50. What is the Scaramucci Post? 'We have absolutely no idea! Retrieved from: pic.twitter.com/lCyGJXG04u (accessed 20 December 2018).

\section{Information about the author: Yuliia Hlavatska, $\mathrm{PhD}$ in Philology,} The Head of the Department of Theory and Practice of Translation and Applied Linguistics, Kherson State University

47, Inzhenera Korsakova provulok, Kherson, 73000, Ukraine ORCID ID: orcid.org/0000-0002-1162-0251 